\title{
PSYCHOLOGICAL MODEL OF CIVIC IDENTITY FORMATION
}

\author{
INHA PETROVSKA \\ Faculty of Philosophy, Department of Psychology \\ Ivan Franko National University of Lviv \\ Universytetska 1, 79000 Lviv, Ukraine \\ E-mail address: inha.petrovska@lnu.edu.ua \\ ORCID: https://orcid.org/0000-0001-7544-945X
}

\begin{abstract}
Aim. The research aims to present the psychological concept of civic identity formation, namely author's view on the nature of civic identity, the stages and psychological mechanisms of civic identity formation.

Methods. A system of general scientific methods was used: analysis and synthesis of the main provisions of research sources on the study of civic identity as a complex multidimensional personality formation, comprehension of the psychological foundations of civic identity, systematisation and generalisation of scientific provisions on the stages and mechanisms of identity.

Results. It is proposed to consider civic identity as a kind of organisational identity, which is self-determination in the organisational environment of the state, as well as selfidentification with the role of a citizen and is the primary psychological regulator of civic behaviour. The main stages of civic identity formation are: perceptual-systemic, normativecommunity and individual-integrational. The main mechanisms of formation of civic identity are: internalisation of stereotypes and attitudes of citizenship; imitation of models of civic behaviour; individuation of the meanings (sense) of citizenship; exteriorisation of stereotypes, attitudes and patterns of civic behaviour; implementation of the experience of interaction with the state and fellow citizens; comprehension of one's own citizenship.

Conclusions. Formation of civic identity (civic protoidentity - reproductive civic identity - productive civic identity) is a dynamic process that has staged nature as it involves a series of successive stages, at each of which civic identity undergoes qualitative changes and is formed as an individual's awareness and reflection of his/her place, role and degree of activity in the system of interaction with other citizens and the state.

Key words: civic identity, psychological mechanisms, stages of formation, civic socialisation, citizen, state, psychological model
\end{abstract}

\section{INTRODUCTION}

Dsychological understanding and psychological analysis of civic identity have more pronounced specificity than understanding and analysis in related sciences such as law, political science and sociology. 
For the above sciences, the definition of civic identity comes down to establishing the formal affiliation of a person to the state as a citizen. It is not always crucial for political science or legal analysis what the community's historical memory of the struggle for/realisation of statehood is, which are the dominant stereotypes, attitudes or expectations about citizenship.

It should be noted that citizenship can be perceived but not accepted or not fully internalised by the citizen, resulting from which the change of citizenship does not pose any psychological problems. The public declaration of citizenship and the actual existence of civic identity as a personal substructure often do not coincide.

This is especially noticeable in countries with a short experience of statehood. A new civic identity does not emerge immediately at the time of the declaration of independence. Therefore, it can be amorphous or partially formed. Accordingly, in difficult times for the state, citizens can easily renounce their citizenship - both by emigration and by «legal» voting for the transfer of the territory in which they live to another state. The situation is similar to the problem of staff turnover in the organisation when employees are only formally loyal, often fired, and sometimes cooperate with competing organisations.

Scientific interest in the problem of civic identity formation is attributable to the lack of its holistic psychological concept, the validity of psychological mechanisms and stages of its formation and deep comprehension of civic identity as a psychological phenomenon as an individual experience and awareness of citizenship.

\section{THE CONCEPT OF CIVIC IDENTITY. CIVIC IDENTITY AS A KIND OF ORGANISATIONAL IDENTITY}

Attention to civic identity has become especially pronounced in the last two decades. Scholars are trying to determine the essential characteristics of civic identity (Bellamy, 2008; Hart, Richardson, \& Wilkenfeld, 2011; Knefelkamp, 2008), differences between civic identity and ethnic and national identities (Hristova \& Cekik, 2013; Pakulski \& Tranter, 2000; Taljunaite, 2013; Yates \& Youniss, 2006) and its structural components (Cohen \& Chaffee, 2013; Petrovska, 2017; Sanchez-Mazas \& Klein, 2003; Sekulić \& Šporer, 2008).

Recently, in scientific discourse, the tendency to not distinguish the concepts of national, state and civic identities is observed, and such terms as nationalcivic identity (Bushuev \& Titov, 2011; Drobizheva, 2008; Miller, 2000) or statecivic identity (Arutyunova, 2007; Bellamy, 2008; Isin \& Wood, 1999) are used.

First of all, civic identity presupposes self-determination as a citizen regardless of ethnic roots and national origin. Citizens as members of the organisation (state) are united by common organisational values and common problems, limitations, and opportunities of a particular organisational environment of the state. Therefore, civic identity, in contrast to national, is abstracted from ethnic origin and ethnonational culture. For example, an ethnic Chinese - citizen of 
the United States - may have an American civic identity (solidarity with other Americans, involvement in American politics, understanding of the problems of the modern United States), but his or her ethnonational identity may remain Chinese (commitment to ethnic cuisine and clothing, etc.).

The civic identity is associated with the awareness and experience of belonging to a state and the community of its citizens (Sanchez-Mazas \& Klein, 2003). The state is a special form of organisation of society, which is necessary to maintain its integrity, manageability and realisation of social needs and interests of its citizens (Ahrne, 1994).

In our opinion, the state can be considered a social organisation, as analysing the main features of social organisations (associations of people, social community; building social relations based on the regulation of relations, statuses, norms; the presence of a coordinating institution and management system; interaction with the external environment) proves that all of them are inherent in the state (Petrovska, 2018). As Anton Oleinik (2002) rightly remarked that, "after a firm, another type of organisation is the state, which should be considered not as an institution but as a special organisation" (p. 344).

As a result of immersion in the organisational environment of the state, the individual gradually develops a relevant organisational identity - according to organisational identification (Ashforth \& Mael, 1989; Dutton, Dukerich, \& Harquail, 1994; Harris \& Cameron, 2005; Yasin \& Sinem, 2015). Figuratively speaking, this identity answers the question "Who am I in this system? Whom do I want and whom can I be in this organisation?". Questions and answers are not always conscious, but they are meaningful about the possibilities of survival and self-realisation in this organisational reality, the acceptance of values and rules (both explicit and implicit) of this organisation. This is the self-determination of an individual in the organisational reality of the state.

Self-determination develops due to self-categorisation (so as, in particular, ethnic, professional self-determination). Self-categorisation is an essential process in identity formation; its avoidance leads to amorphous identity, making self-determination impossible (Ellemers, Kortekaas, \& Ouwerkerk, 1999; Turner, 1985).

It should be emphasised that the self-determination mentioned above and the resulting identity regulate the organisational behaviour of the individual - civic behaviour. We use the term "civic behaviour" not in the sense of "correct," socially acceptable actions towards the state, but in the scientific and psychological sense, i.e., any person's behaviour towards the state; actions of a person in the status of a citizen. For example, both payment and non-payment of taxes are civic behaviours; participation or non-participation in elections as a voter are civic behaviours; change of citizenship or staying in the status of a citizen of the same state are civic behaviours.

Thus, civic identity is considered by us as a kind of organisational identity, which is self-determination in the organisational environment of the state, as well as self-identification with the role of a citizen and is the primary psychological regulator of civic behaviour. 


\section{STAGES OF CIVIC IDENTITY FORMATION}

The functioning of the civic identity of the individuals is intended to facilitate their adaptation to the state's organisational environment, optimise their social self-realisation, and join forces with fellow citizens for the development of the state. Civic identity is formed gradually, and the achievement of civic maturity is difficult to rigidly "tie" to a particular age. The formation of the civic identity of the individual goes through certain stages, which are sequential.

The first stage (perceptual-systemic) takes place in the parental family. The most important process for the development of civic identity - the formation of the primary organisational identity: the experience of self as an element of the family system occurs. At this stage, a civic protoidentity is formed.

Even in early childhood, an individual perceives not only certain people (mother, father, siblings), but also the whole family as a system. This means that it reflects the integrity of the family (integral primary to its parts, and therefore it is perceived first), unconsciously reflects its psychological climate (degree of conflict, tension in relationships, strength of ties and trust, etc.). Therefore, in early childhood, a person gets acquainted not only with individuals but with a whole group, and more - with the organisation. He/she accepts their status in this family, as well as their rights and responsibilities. It is important to get acquainted with the positions of power and its distribution among family members, as well as unwritten rules - norms of behaviour and family traditions.

The family is the first organisational reality for an individual, the source of organisational identity. The peculiarity of this stage of formation of the first organisational identity - family - is the integrity of the social perception of the organisation, its emotional nature and universality (the image of the family as an organisation is engraved for life, so the images of other organisations to which a person is a member, are "layered" on this primary image).

Although this primary organisational identity is latent and undeveloped, it already allows individuals to function in the organisation, particularly in the state's organisational environment. Even if a person's life develops so that all subsequent processes of civic identity formation will not take place, the primary organisational identity will provide them with a minimum of behavioural adequacy in the organisational environment of the state.

Although the process described above lasts in a concentrated form during childhood, in general, the social perception of organisations and the most universal of them - the state - lasts from early childhood to old age.

The second stage of civic identity formation (normative-community) is related to being in educational institutions. The result of this stage of civic socialisation is, in our opinion, the formation of reproductive civic identity. Its characteristic features are the development of a certain standard (ideal) of a citizen, orientation on the community (peers), normative civic behaviour, its conformity (willingness to borrow someone else's civic position, views and behaviour) or protestation (readiness to defend their civic views). 
The problem of this stage is the acceptance or non-acceptance by the pupil (student) of the specified standard of the citizen. The obstacle is not that the ideal of the citizen is successful or unsuccessful itself; the main thing is that it must meet the requirements of the time and the peculiarities of the society. The success of the "implantation" of a citizen's standard depends on its compliance with the modern requirements, and if there is no such compliance, this standard is perceived as artificially imposed and causes resistance.

Therefore, in the school period of civic socialisation, either civic conformity or civil protest is often formed as a manifestation of civic identity. Both conformity and protest are normal forms of civic identity, although they are immature, they are developing. However, this immature civic identity is often fixed: a person remains a "rebel" against the state for the rest of the life, does not admit its power and laws; or, conversely, remains superficially conformist, pretends to accept the most typical civic stereotypes and guidelines, but in fact, is deeply alienated from their citizenship.

The third stage of formation of civic identity (individual-integrational) is connected with the beginning of practical realisation of own life plans in organisational environment of the state, in particular, with the beginning of professional activity and building of own career, gaining personal experience of activity in an organisational environment of the state. This is the stage of achieving civic maturity and forming a productive civic identity. During this period, a person develops their own attitude to the state and fellow citizens; its citizenship gains sense.

The content of civic attitudes will depend on the perception of opportunities/ conditions of self-realisation in the organisational environment of the state, security (stability, availability of social guarantees), social recognition. On this basis, the awareness and understanding of the content and meaning of life as a citizen are formed. The new formation of this stage is the emergence of personal civic position.

At this stage, the individualisation of civic identity occurs; interaction with the state acquires a personal meaning. If the motives of avoidance of responsibility escape from organisational self-determination dominate, surrogate ways of interaction of the person with the state are formed.

\section{MECHANISMS OF CIVIC IDENTITY FORMATION}

These mechanisms are a set of states and processes that unfold over time (in parallel or sequentially), prompting and «triggering» the following ones, which results in the formation and development of civic identity.

Thus, the mechanisms of origin of civic identity include:

- internalisation of stereotypes and attitudes of citizenship;

- imitation of models of civic behaviour (includes two mechanisms: the choice of subjective-attraction model and imitation of civic behaviour of the model). 
The resulting state of these processes is civic protoidentity.

The mechanisms of development include:

- individuation of the meanings (sense) of citizenship;

- exteriorisation of stereotypes, attitudes and patterns of civic behaviour.

The result of these processes is a reproductive civic identity.

We refer to the mechanisms of the actual formation:

- implementation of the experience of interaction with the state and fellow citizens;

- comprehension of one's own citizenship.

As a result of the entire course of all these processes, a mature civic identity emerges as a personal formation, i.e., a productive civic identity.

Let us consistently consider the main mechanisms of civic identity formation, working at the level of consciousness and the surface layers of the unconscious.

\section{THE MECHANISMS OF ORIGIN OF CIVIC IDENTITY}

The mechanisms of internalisation of stereotypes and attitudes of citizenship and imitation of models of civic behaviour play a dominant role in childhood and can act simultaneously when the primary civic socialisation occurs. These mechanisms presuppose the presence of authoritative persons in the field of social perception of the child, whose actions are personally significant for him or her. It is possible to distinguish verbal and nonverbal actions:

a) statements about the state and citizenship (assessments, judgments, reasoning);

b) acts of civil conduct (voting in elections, participation in the work of public organisations, preparation for emigration and its implementation, etc.).

The first type of action in most cases conditions the reproduction of the most common stereotypical judgments in society, typical attitudes towards the state, while the second type causes the certain behavioural acts to manifest in certain situations.

The interiorisation of stereotypes and attitudes of citizenship is a mechanism that begins to work quite early and consists, firstly, in memorising, and secondly, in reproducing the information heard (Samylova, 2013) about the state and citizenship. The channels for receiving information, as well as the form and content of messages about the state and citizenship, can be varied: from direct instruction from parents (these can be complaints, assessments, abusive remarks) to "unbiased" information from official television channels or in history lessons at school.

The form of reproduction depends on the attitude to the authoritative person and the life situation of the individual. The attitude can be reproduced "close to the text" (for example, in preschool and early school age) or with the opposite meaning (for example, in adolescence). In any case, the child is tied 
in their political and civic thinking to this, once and for all, learned parental judgment, which is usually stereotypical. But the nature of this attitude can be different, both conformal and nonconformal.

Personality interiorises many stereotypical statements containing assessments of the state and expresses typical attitudes and expectations about it. It should be noted that this mechanism is not decisive for further formation of civic identity because information can be selected by various filters, distorted, forgotten or lose its relevance. Nevertheless, what was heard or read can be helpful for argumentation (rationalisation) of the chosen civil position.

The mechanism of imitation of models of civic behaviour makes a more significant contribution to the formation of civic behaviour than the previous mechanism and involves the repetition of the observed behaviour of an authoritative person. The model of imitation can be an authoritative person, who, firstly, is often "in sight" of the subject of imitation, and secondly, implements "successful" behaviour (receives social approval or other positive reinforcements) (Bandura, 1962).

Thus, firstly, the process of imitation involves the choice of models of civic behaviour (objects of imitation). This choice is made by evaluating the persons available for imitation. The peculiarity of choice is the orientation not on the civic or political behaviour of the model and its perceptual effectiveness but the subjective attractiveness and referentiality of the individual. These properties often depend on the cognitive accessibility of the model's behaviour, its suitability for imitation, the level of its social acceptance.

The model of imitation is often one of the parents. It is noteworthy that in the case of a mismatch between parental instructions (expressed orally) and parental civic behaviour, preference is given to behaviour. Secondly, the choice of the model of imitation entails the following process - the actual imitation of its behaviour, including civic behaviour.

The way of reproducing the model of civic behaviour can be different: from duplication of individual actions to the reproduction of the whole chain of actions, which allows reproducing the situation's logic as a whole. This reproduction reveals the level of the child's understanding of the political (civic) situation, which can be very different, in which the political (civic) intellect of the child's personality manifests itself. The implementation of civic behaviour presupposes its further substantiation, rationalisation, which enforces further self-determination in relation to the state and, accordingly, the extraction of one's own civic identity.

\section{THE MECHANISMS OF DEVELOPMENT OF CIVIC IDENTITY}

The mechanisms of development are the individuation of the meanings (sense) of citizenship and the exteriorisation of stereotypes, attitudes and patterns of civic behaviour.

Individuation of the meanings (sense) of citizenship is carried out after 
their internalisation and mastering the elements of civic behaviour during its imitation. It is the inclusion of citizenship as a cognition introduced from outside into the system of personal meanings (Tytarenko, 2013), individualisation of all significant meanings of the state, fellow citizens, and own citizenship. As a result of this process, the civic identity of the individual acquires uniqueness and originality in accordance with the personal authenticity of its bearer.

The state that is achieved by civic identity in the course of the implementation of development mechanisms is the state of reproductive identity. Its characteristic features are community orientation (mainly peer), conformity (willingness to borrow someone else's civic position, views and behaviour) or protest (readiness to defend their civic views).

In our opinion, the mechanism of individuation of the citizenship meanings begins to work in the context of protest. Firstly, it includes the initial (new to the young person) experience of their personal meanings of citizenship. The second link of this mechanism is the experience of these meanings as important and meaningful, therefore "better," "more correct" than others. This perception of one's views as super-valuable corresponds to youthful maximalism, which is also interpreted as a manifestation of personal immaturity. However, all this is a natural stage of development: first, a person needs to cultivate their own unique views, and only much later, a tolerance for the views of others develops. Therefore, the third link in the individuation of the citizenship meanings is to protect them meanings as unique.

The desire to protect citizenship meanings is not least due to their vulnerability to any criticism, immaturity, imperfection. That is why these immature, but their own, views are defended with true youthful maximalism. The task of individualising them dictates the need for this stage, that is, to make them part of the self of the individual because according to Carl Jung, individuation is a process of individual's movement to the formation of "own self" (Jung, 1969).

In our opinion, this mechanism operates throughout the life, encouraging the constant development of the human personality in general and civic identity as its formation in particular.

Exteriorisation of stereotypes, attitudes and patterns of civic behaviour is based on the internal results of civic individuation and is their embodiment in external forms - civic acts, actions, activities. Just as the artist expresses inherent moods, ideas, experiences in their works or the individual embodies their inner potential in life, the citizen realises their individualised civic positions in the relevant civic activities and actions.

\section{THE MECHANISMS OF ACTUAL FORMATION OF CIVIC IDENTITY}

The mechanisms of the actual formation of civic identity include implementing individual experience of interaction with the state and fellow citizens and comprehension of one's own citizenship. 
The implementation of individual experience of interaction with the state and fellow citizens is one of the most important mechanisms for the formation of civic identity. In contrast to the previous mechanism, this is not only about the skills of civic behaviour, but about the construction of separate purposeful activities in the organisational environment of the state, motivated and regulated. This mechanism is based on the previous ones, as it includes both acquired information and acquired skills.

This process begins with motivation and goal setting. The most common motivation is financial support for one's life, raising the social status (building a career) and achieving success and acceptance from others. These goals are possible to achieve only in an organised environment (at least in terms human society). It is the state that creates standards for most organised environments and regulates interaction in them (Oleinik, 2002). Therefore, understanding the real practice of relations in the organisational environment is important to achieve these goals.

First of all, there are two such dimensions of the organisational environment, as hierarchical and legal. The first involves learning how hierarchies work in organisations as gaining status and building a career is impossible without it. The second means not only knowledge of the laws and willingness to abide by them but also orientation in real legal practice (which may differ from the formally proclaimed norms).

Finally, on the basis of the acquired information, imitation (learning) and individual experience of individual's activity in the organisational environment of the state, another important mechanism of formation of civic identity comes into play - comprehension of own citizenship. In the course of this comprehension, the civic position is crystallised, the authentic civic values of the individual are determined, and on this basis one's belonging to the community of citizens and to the state is comprehended. A distinction is made between borrowed and own meanings and attitudes towards the state and one's personal citizenship.

In our opinion, both mechanisms (implementation of individual experience of interaction with the state and fellow citizens and comprehension of own citizenship) act simultaneously and condition the final stage of formation of civic identity and its result - mature (formed) civic identity.

At the same time, these two mechanisms complement each other. Thus, the mechanism of comprehension includes the processes of reflection, social perception of the state, construction of its image, sense-giving to acts of interaction with the state and fellow citizens. These processes precede the "activation" of the implementation mechanism, which involves a sequence of processes: developing a model of successful behaviour, implementing it and correcting one's behaviour during the interaction with the state and fellow citizens. As we can see, the nature of these processes is such that they, in turn, trigger the action of the mechanism of comprehension. The resulting state achieved due to these mechanisms is the maturity (formed) civic identity.

Thus, the implementation of all the above mechanisms allows the formation of mature civic identity. 


\section{CONCLUSIONS}

Civic identity is a kind of organisational identity, which is self-determination in the organisational environment of the state, as well as self-identification with the role of a citizen and is the primary psychological regulator of civic behaviour.

Civic identity is formed in the process of civic socialisation, which we consider as the process of gaining social experience of citizenship by an individual (norms and values of civic culture, patterns of civic behaviour, knowledge and ideas about the state, citizenship, etc.) by inclusion in the organisational environment of the state and social relations with other citizens.

Summarising the results, we propose a theoretical model of civic identity formation (Fig. 1).

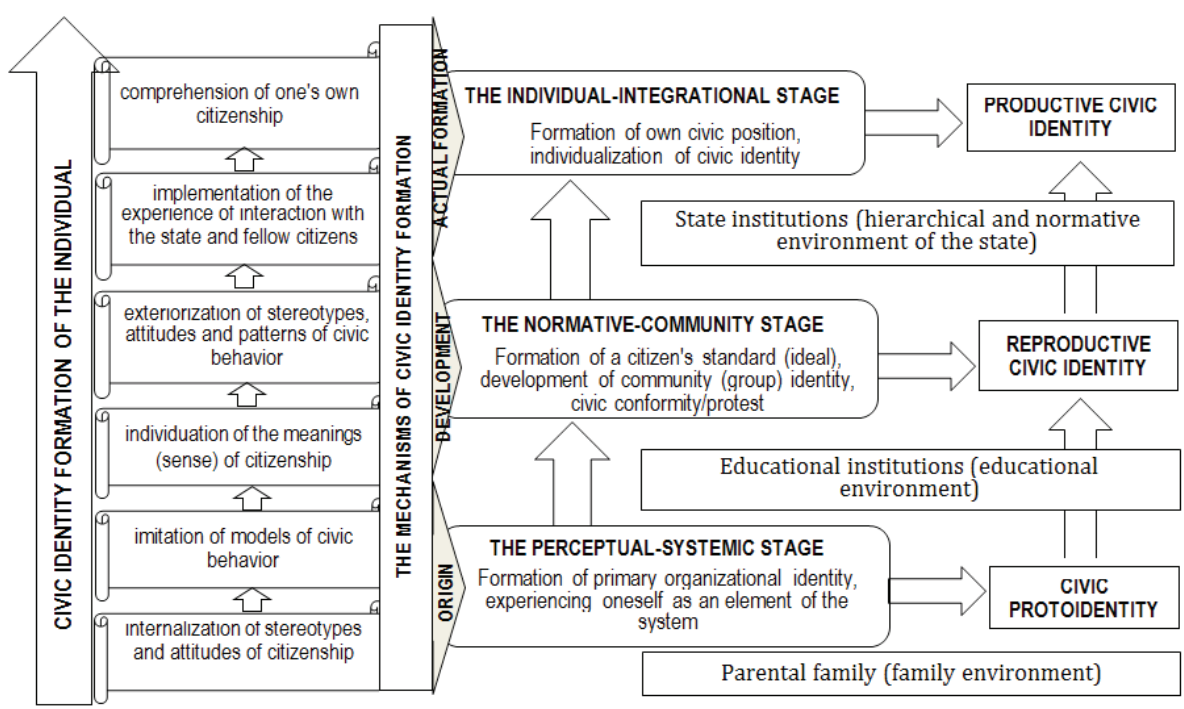

Fig. 1. Theoretical model of civic identity formation of the individual.

Source: Own research

The formation of civic identity (civic protoidentity - reproductive civic identity - productive civic identity) is a dynamic process that covers a number of successive stages (perceptual-systemic, normative-community, individualintegrational), during each of which civic identity undergoes qualitative changes and is formed as individual's awareness and reflection of their place, role and degree of activity in the system of interaction with other citizens and the state, involves the acquisition of a person's appropriate organisational identity, as well as mastering the role repertoire of the citizen.

The mechanisms of formation of civic identity include the mechanisms of origin (internalisation of stereotypes and attitudes of citizenship; imitation of models of civic behaviour), mechanisms of development (individuation of the meanings (sense) of citizenship; exteriorisation of stereotypes, 
Journal of Education Culture and Society No. 2_2021

attitudes and patterns of civic behaviour) and mechanisms of actual formation (implementation of the experience of interaction with the state and fellow citizens; comprehension of one's own citizenship).

\section{REFERENCES}

[1] Ahrne, G. (1994). Social organisations: Interaction inside, outside, and between organisations. London, GB: SAGE Publications Ltd.

[2] Arutyunova, Е. (2007). Формирование государственно-гражданской идентичности молодежи [Formation of state-civic identity of youth]. Moscow: RUDN University.

[3] Ashforth, B. E,. \& Mael, F. (1989). Social identity theory and the organisation. The Academy of Management Review, 14(1), 20-39.

[4] Bandura, A. (1962). Social learning through imitation. University of Nebraska Press: Lincoln, NE.

[5] Bellamy, R. (2008). Citizenship: A very short introduction. Oxford, UK: Oxford University Press.

[6] Bushuev, V., \& Titov, V. (2011). Национально-государственная идентичность в современном мире и роль исторической политики в ее формировании (теоретико-методологический анализ) [National-State Identity in the modern world and the role of historical politics in its formation (theoretical and methodological analysis)]. Bulletin History and Political Science, 4, 77-93.

[7] Cohen, A. K., \& Chaffee, B. W. (2013) The relationship between adolescents' civic knowledge, civic attitude, and civic behaviour and their self-reported future likelihood of voting. Education, Citizenship and Social Justice, 8(1), 43-57.

[8] Drobizheva, L. M. (2008). Национально-гражданская и этническая идентичность: проблемы позитивной совместимости [National-Civic and Ethnic Identity: problems of positive compatibility] In: Russia reforming. Yearbook - 2008 (pp. 214-228). Moscow: Institute of Sociology RAS.

[9] Dutton, J. E., Dukerich, J. M., \& Harquail, C. V. (1994). Organisational images and member identification. Administrative Science Quarterly, 39, 239-263.

[10] Ellemers, N., Kortekaas, P., \& Ouwerkerk, J. W. (1999). Self-categorisation, commitment to the group and group self-esteem as related but distinct aspects of social identity. European Journal of Social Psychology, 29, 371-389.

[11] Harris, G. E., \& Cameron J. E. (2005). Multiple dimensions of organisational identification and commitment as predictors of turnover intentions and psychological well-being. Canadian Journal of Behavioural Science, 37, 159-169.

[12] Hart, D., Richardson, C., \& Wilkenfeld, B. (2011). Civic identity. In: S. J. Schwartz et al. (Eds.), Handbook of identity theory and research (pp. 771-787). New York: Springer

[13] Hopkins, N., Reicher, S., \& Kahani-Hopkins, V. (2003). Citizenship, participation and identity construction: Political mobilisation amongst British Muslims. Psychologica Belgica, 43, 33-54.

[14] Hristova, L., \& Cekik., A. (2013). Between the ethnic and the civic identity - on the perceptions of the student population in the Republic of Macedonia. New Balkan Politics, 13, 45-70.

[15] Isin, E. F., \& Wood, P. K. (1999). Citizenship and identity. London: Sage.

[16] Jung, C. G. (1969). Aion: Researches into the phenomenology of the Self. The collected works of C. G. Jung: Volume 09/2 (H. Read et al., Eds.). Princeton, NJ: Princeton University Press.

[17] Knefelkamp, L. (2008) Civic identity: Locating self in community. Diversity \& Democracy, 11(2), 1-3.

[18] Miller, D. (2000). Citizenship and National Identity. Cambridge: Polity.

[19] Oleinik, A. N. (2002). Институциональная экономика: Учебное пособие [Institutional economics: Textbook]. Moscow: INFRA-M.

[20] Pakulski, J., \& Tranter, B. (2000). Civic, national and denizen identity in Australia. Journal of Sociology, 36(2), 205-222.

[21] Petrovska, I. R. (2017). Рівні та структура громадянської ідентичності [Civic identity level and structure], Psychological Perspectives, 30, 157-171. 
[22] Petrovska, I. R. (2018). Громадянська ідентичність як різновид організаційної ідентичності [Civic identity as a kind of organisational identity]. Problems of Modern Psychology, 39, 244-257.

[23] Riketta, M. (2005). Organisational identification: A meta-analysis. Journal of Vocational Behaviour, 66(2), 358-384.

[24] Samylova, O. (2013). Психологические механизмы духовно-нравственного развития в юношеском возрасте [Psychological mechanisms of spiritual and moral development in juvenile]. Bulletin of Surgut State Pedagogical University, 3, 129-133.

[25] Sanchez-Mazas, M., \& Klein, O. (2003). Social identity and citizenship: Introduction to the special issue. Psychologica Belgica, 43(1-2), 1-8.

[26] Sekulić, D., \& Šporer, Ž. (2008). European and Croatian identity. Sociologija i proctor, 46(1), 13-22.

[27] Taljunaite, M. (2013). From ethnic and civil identity towards state identity. Filosofija-Sociologija, 24(4), 187-192.

[28] Turner, J. C. (1985). Social categorisation and self-concept: A social cognitive theory of group behaviour. In: E. J. Lawler (Ed.), In advances in group process: Theory and research (pp. 77-121). Greenwich, Connecticut: JAI Press.

[29] Tytarenko, T. (2013). Сучасна психологія особистості [Modern psychology of personality: Textbook for university students]. Kyiv: Caravel.

[30] Yasin, Ö., \& Sinem, E. (2015). The relationship between organisational socialisation and organisational citizenship behaviour: the mediating role of personenvironment fit. Social and Behavioural Sciences, 207, 432-443.

[31] Yates, M., \& Youniss, J. (2006). Roots of civic identity. International perspectives on community service and activism in youth. Cambridge: Cambridge University Press. 